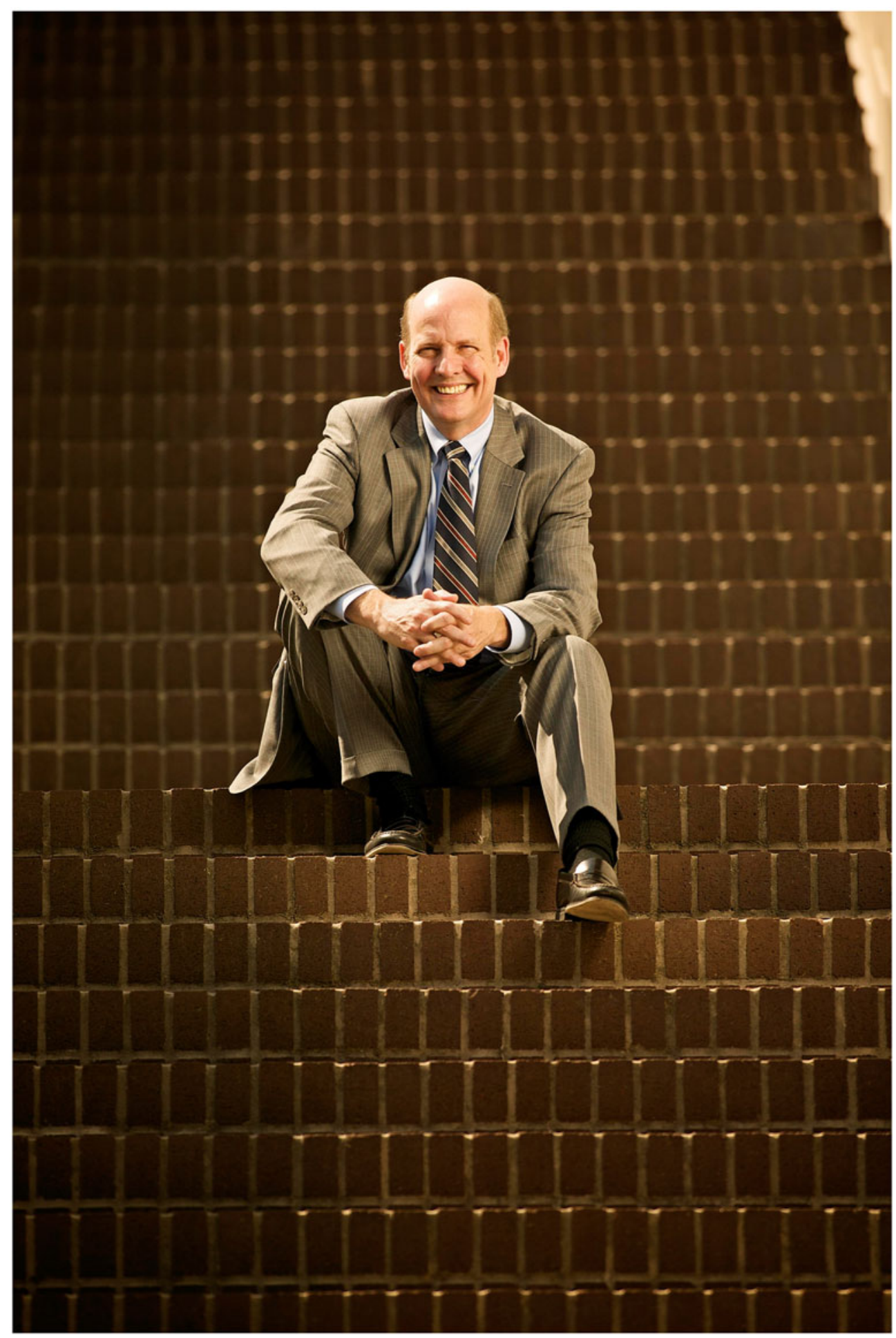




\title{
A TRIBUTE TO FRANK S. ALEXANDER
}

\begin{abstract}
"A time of troubles," in Toynbee's words, is a period of crisis in law and values - a loss of faith in law and in the presence of principles underlying the law. Today is just such a time - the authority of law has disintegrated into lawless authority. . . . Cries for the protection of human life are heard in our hospitals, and in our prayers, but we are confused as to when life begins, or when it ends. Demands for stiffer, mandatory sentences [without pardons] for those convicted of crimes abound in Congressional bills, while in our synagogues and churches we wrestle with the meaning of acceptance, reconciliation, and forgiveness. Whispers of despair and anguish are heard on the lips of children canght in the midst of divorce fights and custody battles, and on the lips of parents as children are sentenced to institutional life, while we wonder about the values of the nuclear family. Religious structures and perspectives have lost the prophetic ability to critically evaluate these laws and to speak truth to power, and legal structures have lost the interest and ability to discern underlying values of law which have now begun vague and confused.
\end{abstract}

This statement could well have been from an op-ed in today's newspaper lamenting the crisis of our day. But these words were written in I977. They are the opening lines of the ten-page "Statement of Essence" issued by what was then a new organization, the Council on Religion and Law, Inc., or CORAL. This was initially a group of professors, students, attorneys, social service professionals, and ministers of different faiths at Harvard and in the greater Boston area. Over the prior year, they had gathered periodically to address the escalating national crisis of their day. Their crisis was born of the Vietnam War, Watergate, racial conflicts, massive inflation, economic recession, blighted housing, new immigration restrictions, the global oil crisis, and more, sparking rampant public protests, street fights, riots, looting, and crime. Offering one constructive response, the CORAL Statement called for a comprehensive "interreligious, interdisciplinary, and interprofessional" movement focused on the interaction of law and religion in teaching, practice, and service.

CORAL proved to be a vital incubator for the fledgling study of law and religion around the country. The group organized its first conference, "Symposium on Theology and Law: Responsibilities of Vocation," held at Harvard Law School in I977. CORAL board members fanned out to convene "regional task forces" around the country to collect data on existing courses and programs in law and religion, discovering new initiatives at Berkeley, Catholic, Vanderbilt, Notre Dame, and Louisville, and various courses in Jewish law, canon law, natural law, religious freedom, church-state relations, and law and theology at nine other schools. The group assembled model curricula and bibliographies of law and religion study in law schools, seminaries, and continued legal and pastoral education programs. It created a directory of professors and practitioners, and it sponsored interlinked clinical programs that sought to integrate legal, pastoral, health care, and social services. CORAL board members led the creation of the Law and Religion Section of the Association of American Law Schools and the Committee on Religion and Ethics of the Society of Christian Ethics. By 1978, the CORAL leadership had in hand an ambitious proposal, the "Ecumenical Institute for the Study of Law and Theology," which would integrate and expand all these efforts and, ideally, be home to a new interdisciplinary journal in law and religion. By I982, this idea of an "Ecumenical Institute" came into being as the new Law and Theology 
Program at Emory University, now in its thirty-eighth year of operation. In I983, CORAL launched the Journal of Law and Religion at Hamline University; the journal is now housed at Emory and set to publish volume 36 .

Several dozen major scholars were part of CORAL's early efforts, a number of whom remained leaders of the law and religion movement and regular contributors to this journal: James Luther Adams, Frank Alexander, Milner Ball, Harold Berman, James Bresnahan, Lynn Buzzard, Lisa Cahill, James Coriden, Roger Cramton, Charles Curran, Marie Failinger, Lois Forer, Edward Gaffney, Howard Lesnick, Jerome Hall, David Little, Martin Marty, Nancy Miller-Herron, Noor Mohammed, John Noonan, Thomas Porter, Thomas Shaffer, Max Stackhouse, William Stringfellow, Douglas Sturm, Howard Vogel, and Wilson Yates, among many others. All of us who work in the field of law and religion study today owe deep debts of gratitude to this founding generation and the pioneering and nurturing efforts of CORAL.

Frank S. Alexander was the moving force of CORAL. Indeed, Harold Berman quipped in I977, "CORAL is just the acronym for Frank Alexander." His experience with this group shaped his own work and vocation as much as CORAL shaped the field of law and religion study. Frank was a brilliant student at Harvard Law School and Harvard Divinity School at the time, having graduated Phi Beta Kappa at the age of twenty from the University of North Carolina, where he had been a Morehead Scholar. He worked closely with Berman at the law school and with James Luther Adams at the divinity school. Already as a second-year student in 1975 , he proposed the creation of CORAL in a lengthy report, "Religion and Law: Opportunities for Creative Dialogue," presented to the deans of the law school and divinity school. For the next year, he worked between classes to assemble the initial leadership of CORAL, and to organize its first meetings and activities. He helped draft the 1977 "Statement of Essence" of CORAL, with which we began, and he helped prepare the founding charter, tax exemption documents, and financial reports. He was the convenor of that first I 977 conference. He drafted the first plan for an ecumenical institute, which he later used to charter the Law and Theology Program at Emory. He likewise helped draft the charter of the Journal of Law and Religion as a joint venture of Hamline and CORAL. And throughout those early years of CORAL's work, Frank kept meticulous records-detailed notes and formal minutes of meetings, financial reports calculated to the penny, detailed contracts drafted for all manner of services and products, letters, and reports galore. Our Emory Law School archives hold two large bankers boxes jammed full of documents from these early years, many of them bearing Frank's inimitable southpaw angular penmanship.

All this was vintage Frank Alexander-at once bold and visionary, creative and collaborative, assiduous and meticulous in his legal work. Here was a scholar who pursued "the weightier matters of the law: justice and mercy and faith," but always in tandem with the legal technicalities: the "mint, dill, and cumin," as Matthew 23:23 put it. He insisted on the interaction of theory and practice, town and gown, the academic and the practitioner. He insisted that both the legal profession and ministerial profession were called to serve all sectors of society, including notably those whom the Bible called "the least" of society-widows, orphans, prisoners, debtors, the poor, the disabled, and other personae miserabiles. Frank took to heart Saint Paul's egalitarian admonition that in a truly just society there is "no real division between Jew and Gentile, slave and free, male and female" (Galatians 3:28)-or, for that matter, black and white, straight and gay, old and young, rich and poor, citizen and sojourner, native and immigrant.

These norms and habits proved to be enduring hallmarks of Frank Alexander's thirty-year tenure as an Emory law professor, which we celebrate in this tribute to him on his retirement. After four years of practice in real estate law and finance in Atlanta, he was appointed first as an adjunct professor teaching "Law and Theology" in I98I and I982, and then as assistant professor of law 
in the fall semester 1982. He retired this past spring as the Sam Nunn Professor of Law Emeritus. He spent his entire career at Emory, except for a sabbatical year at his alma mater in Chapel Hill. He served as interim dean in 2005-2006, raising substantial new endowment funds and coordinating the Law School's ambitious and generous response to the devastation of Hurricane Katrina by welcoming Tulane Law School students and housing their information technology programs at Emory Law School.

From the start, Frank proved to be a superb teacher and mentor. Some eight thousand students took his courses in property, real estate law and finance, state and local government law, federal housing policy, and law and theology. Some two hundred and fifty students wrote their law journal notes under his supervision. In his teaching and mentorship, he moved easily from high legal theory to nitty gritty legal practice. He was equally famous for his demanding Socratic teaching style and his gentle pastoral care for his students. He was a stickler for detail, for playing by the book, and for being on time, but he would move heaven and earth to help a student, alum, or colleague in real need. He won every major teaching award offered by Emory: the Thomas Jefferson Award, two Crystal Apple Awards for Professional School Teaching, five Most Outstanding Professor of Emory Law School awards, the Ben F. Johnson Faculty Excellence Award, and the Emory Williams Award for Distinguished Teaching. For his first eight years on the faculty, the students voted him the Professor Who Best Exemplifies the Ideals of the Legal Profession, until the administration quietly canceled the award, no doubt to spare the rest of the faculty from being further upstaged.

Frank produced a great deal of high-quality scholarship in this period as well, captured in some fifty titles, among them Create Affordable Housing for All; Georgia Real Estate Finance and Foreclosure Law (now in its fifteenth edition); Land Banks; The Encyclopedia of Housing; and Neighborhood Stabilization Strategies for Vacant and Abandoned Properties. These titles were part and product of his far-flung efforts to build innovative "interdisciplinary, interreligious, and inter-professional" projects at Emory and in Atlanta, much like he had done at Harvard and in Boston in the I970s. He worked with Emory students to create the Emory Public Interest Committee, and he quietly guided, funded, and opened doors for this vital form of legal ministry and service. He was deeply involved in serving the East Lake Meadows Project in Atlanta, a public housing project that was fighting redevelopment. He founded the Project on Affordable Housing and Community Development, which provided resources and access to justice for people to have a home or return to it after eviction or bankruptcy. He worked closely with President Jimmy Carter on the Atlanta Project, an ambitious public-private, religion-government cooperative effort to stabilize and enhance distressed neighborhoods in Atlanta. He chaired the Consumer Credit Counseling Service to help those struggling with finances, debts, and loans. He was part of the Community Friendship program to provide services for the chronically mentally ill. He co-founded and still helps lead the Center for Community Progress, a major nongovernmental organization, headquartered in Washington, DC, that enables American state and local governments to revive vacant, abandoned, and blighted properties and put them back into community service. Those efforts earned him several additional awards beyond his teaching hardware: the George A. Pindar Award, the Inspiration Award for Outstanding Leadership in Public Interest, the Outstanding Service Award of the Atlanta Legal Aid Society, the Citizen's Award for Outstanding Service from the Fulton County/City of Atlanta Land Bank Authority, the Georgia Bar Association Award for Outstanding Scholarship, and the EPIC Lifetime Commitment to Public Interest Award, among others. Frank was always gracious and grateful for the recognition, but he usually dumped these awards into boxes headed for the attic, preferring to leave his office shelves for new books and his walls for more family pictures. 
Frank viewed all these efforts as part of his vocation as a lawyer and theologian, and he saw them as central expressions of the practice of law and religion. Complementing these efforts was the Law and Theology Program at Emory University, now called the Center for the Study of Law and Religion. Frank worked with Emory president James T. Laney to create the program in I 982 as part of a larger effort to build a fully interdisciplinary research university at Emory. The program's mission was to increase understanding of the fundamental role of religion in shaping law, politics, and society, and to build bridges of conversation among Jews, Christians, and Muslims about legal subjects. Here, students and scholars could probe the creative dialectics between church and state, religion and politics, faith and law. Here they could come to understand the nuances of Jewish, Christian, and Islamic laws and their place in modern nation-states. Here they could explore the religious dimensions of law, the legal dimensions of religion, and the interaction of legal and religious ideas, institutions, and methods. The Law and Theology Program, with Frank as founding director, aimed to enhance the interdisciplinary understanding of law without diluting rigorous legal study, to widen the horizons of religious education without propagating a particular faith or ideological agenda.

In 1985 , Frank and Jim Laney persuaded Harold Berman to leave Harvard, where he had taught since 1948, and to join Emory as the first Robert W. Woodruff Professor of Law, a university professorship. Berman brought instant stature to Emory's new program and an ambitious research agenda, particularly on the historical interaction of law and religion in the Western legal tradition. I followed Berman to Emory after graduating from Harvard Law School that spring. Remarkably, two years later, Frank voluntarily stepped aside to make way for my appointment as the new program director, allowing me to work alongside him and Berman. The three of us, supported by generous university and foundation funding, slowly expanded our work to build up major interdisciplinary research projects, international conferences, scholarly fellowships and internships, and sundry courses, degree programs, publications, and public forums in law and religion. And we slowly expanded our team of scholars to engage some eighty Emory faculty and sixteen hundred scholars worldwide who now study the interaction of law and religion with us.

Frank and I worked directly together on major research projects, involving hundreds of scholars and ranging widely-among them, Christianity and Democracy in Global Context; The Child in Law, Religion, and Society; and Christian Jurisprudence: Catholic, Protestant, and Orthodox Perspectives. We coedited half a dozen books together-The Weightier Matters of the Law; Christianity and Law; Christianity and Human Rights; and Modern Christian Teachings on Law, Politics, and Human Nature in three volumes - together with several articles. But most importantly, we worked together as friends, colleagues, and brothers. We built programs and projects together. We convened conferences and roundtables. We raised money. We published books. We worked and played. We worshipped and prayed. We sweated and planned. We laughed and cried. We caught fish and swung hammers together. We loved each other as brothers do.

My career, our center, this journal, and the field of law and religion study more generally would not be what it is today without the pioneering work and shaping influence of Frank S. Alexander. All of us at Emory miss his daily presence in the office as he enjoys the well-earned bounties of retirement and grandchildren. But we know that if there is real need, Frank will be the first one to call.

John Witte, Jr.

Robert W. Woodruff University Professor of Law; McDonald Distinguished Professor of Religion; Director, Center for the Study of Law and Religion, Emory University 